\title{
Impact of Educational Leadership on Institutional Performance in Pakistan
}

\author{
Dr. Abdullah Faisal \\ Director, Punjab Education Assessment System (PEAS) \\ University of Education, College Road, Township, Lahore-54770, Pakistan \\ Afaisal111@gmail.com
}

Muhammad Azeem (Corresponding author)

Assessment Expert

Punjab Education Assessment System (PEAS), University of Education, College Road,

Township, Lahore-54770, Pakistan

Knowledge_jhumra@yahoo.com

Farrukh Aysha

Lecturer Education, Govt. Degree College, Township, Lahore, Pakistan aysha.amer@hotmail.com

Farrukh Amina

Lecturer English, National University of Modern languages (NUML), Islamabad, Pakistan farrukhamina@hotmail.com

Dr. Farhat Saleem

Principal, Bank Road Campus, University of Education, Lahore, Pakistan farhatsaleem_ue@hotmail.com

Rubina Nadeem

Senior Expert Accreditation and HRD, Technical Unit

National Vocational and Technical Training Commission (NAVTTC)

bexcellence@gmail.com

Received: December 20, 2011 Accepted: January 28, 2012 DOI: 10.5296/jpag.v2i1.1385 


\begin{abstract}
Purpose: This study was undertaken to identify and describe the impact of leadership behaviour of educational leaders (both relation-oriented and task-oriented) along with demographics on institutional performance for the fulfilment of goals of education as envisaged in national documents.
\end{abstract}

Research Design/Methodology: Three questionnaires namely Leadership Behaviour Description Questionnaire (LBDQ), Institutional Performance Questionnaire (IPQ) and Leadership Demographics Checklist (LDC) were developed for the collection of data. The validity and reliability of the instruments was ensured through experts' opinions and pilot testing. All educational administrators working in educational institutions-schools, colleges situated at district and provincial level formed the population for this study. The population of study was consisted of Principals of Higher Secondary Schools, Degree Colleges and Colleges of Education, District Educational Officers (DEOs), Executive District Officers (EDOs), and their subordinates [DEOs, Dy. DEOs, AEOs and Superintendents] respectively. Leadership Demographics (attributes + situational factors) Checklist was administered to 171educational leaders and 1368 their subordinate / teaching staff. For gathering quick and reliable data all three questionnaires were routed through Additional Secretary (Schools), Education Department. Using that channel more than $90 \%$ data were collected from the field.

Major Findings: The findings of the study revealed that both Relation-Oriented and Task Oriented Behavioural dimensions of educational leaders of the study directly relate to their leadership effectiveness. This evidence also suggests that the strong relationship between these two variables is optional for high leadership effectiveness for achieving the objectives of the organization. The correlation $\mathrm{r}=.73$ shows a strong positive relationship between relation oriented behaviour of educational leaders and institutional performance. Whereas, the correlation $\mathrm{r}=.74$ shows that there is also a strong relationship between task oriented behaviour of educational leaders and institutional performance. Comparison of both behaviours shows that comparatively second relationship is stronger than the previous one even instead of a little difference between their values. Therefore task oriented behaviour of educational leaders has better impact on the performance of institution rather than relation oriented behaviour of educational leaders and institutional performance. Whatsoever are the factors other than educational leaders, the impact of educational leaders on institutional performance cannot be easily ignored.

Originality/Value: Given the findings in this study, a relatively straight forward profile of educational leaders on institutional performance emerges. An effective educational leader according to this study is one who has Task-Oriented Behaviour which reflects the behaviour of the leader as high on relationship i.e. high on consideration, better with professional qualification, interaction with Subordinates/teaching staff enjoyable academic freedom that acts as catalyst in the use of potential of the staff for better instructional efficiency.

Keywords: Leadership, Effectiveness of Leadership, School Improvement

\title{
1. Introduction
}

Educational leaders possess a pivotal role in institutions and the importance of their role cannot be over looked. The job of educational leaders involve among other things, the provision of leadership for staff, coordinating both human and material resources to ensure the achievement of organizational goals. In an organization the educational leader as an administrator influences his subordinates to achieve the goals and objectives of the institution. Hence the administrators should endeavor to influence the behavior of subordinates in order to achieve the goal of the institution. A leader in this regards acts in both formal and informal 
ways to build employee commitment in the organization.

In the light of policy objectives and statements the reconstruction strategies of the new district based education system has been reinforced into people-centered, rights and responsibility-based and service-oriented governance. According to these new-reformed system adjustments, adaptations and assimilation are very much required from the educational leaders for the redressal and treatment of problems of their respective institutions. In this regard Education Sector Reform Programme (ESRP) 2001 is under way through the agenda of education for improving education sector outcomes and other sectoral issues.

\subsection{Objectives of the Study}

The objectives of the study are to:

1. Identify and describe the behavior, demographic attributes and institutional performance of educational leaders perceived by their own teaching/subordinate staff.

2. Explore the relationship of leadership behavior (both relation-oriented and task-oriented) and demographics (attributes and situational factors), on institutional performance, of educational leaders.

3. Find out impact of educational leadership behavior (both relation-oriented and task-oriented) and demographics (attributes and situational factors) on institutional performance.

4. Apprise educational policy makers, planners and decisions makers with the findings of the research for better future planning.

5. Provide a baseline data for students, teachers and researchers for further research work on it.

\subsection{Hypotheses of the Study}

The following null hypotheses are formulated for the study: -

Ho 1 There is no significant relationship between relation-oriented behavior and task-oriented behavior of the educational leaders.

$\mathbf{H o}_{2}$ There is no significant relationship between relation-oriented behavior of educational leaders and institutional performance.

$\mathbf{H o}_{3}$ There is no significant relationship between task-oriented behavior of educational leaders and institutional performance.

$\mathrm{Ho}_{4}$ There is no significant relationship between institution performance and leadership demographics [attributes] of the educational leaders.

Ho5 There is no significant relationship between institution performance and leadership 
demographics [situational factors] of the educational leaders.

\subsection{Significance of the Study}

Little research work has been done to study the impact of educational leadership behavior on institutional performance. Review of researches on behavioral dimension does not provide sufficient guidelines for examining impact of Relation-Oriented Behavior \& Task-Oriented Behavior of a leader and demographics on institutional performance.

This research study may be significant because:

1. It may provide a factual position about the level of competency of educational leader in organizational behavior.

2. It may also provide a platform for decision-makers for adopting appropriate course of action needed by educational institutions for development.

\subsection{Delimitations of the Study}

The Population for this research study was restricted to the heads (Educational Leaders) and their respective subordinates/teaching staff of the educational institutions. Only Relations-Oriented Behavior and Task-Oriented Behavior leadership behavior dimension of educational leaders was assessed on the perception of their subordinates/teaching staff. In the same way the demographic features of the educational leaders was confined to (Attributes and Situational Factors) only.

\section{Traditional Concepts Meaning and Definition of Leadership}

Even though there are differences between definitions, two characteristics of leadership can be observed; leadership is related to the process of influencing others behavior, it is also related to goals development and achievement. leadership is the initiative of a new structure or procedure for accomplishing an organization's goals and objectives or for changing an organization's goals and objectives (Lipham, 1981); a process in which some values, needs and aspirations of both leader and followers are taken care of while acting for achieving certain goals (Bass, 1990); to achieve some goals a leader may direct the activities towards it or may initiate an action among people for a specific purpose (Jacobs \& Jaques, 1990). Searching for the one and only proper and true definition of leadership seems to be fruitless (Bass, 1990).

Leadership possesses as many definitions as the term motivation. It is an elusive, yet very real concept that daily influences every person in every organization in the world. Leadership can be seen as the relationship in which one person (the leader) influences others to work together willingly on related tasks to attain goals desired by the leader and/or group. In this connection leading involves influencing and interacting with people to attain goals.

Boles and Davenport (1975) say that leadership is a process - not a category of behavior, a prerogative of position or personality, nor a collectivity of persons. Kelly (1981) stresses "it is the group that attains goals and not the leader and says that leadership is the performance 
of acts which assist the group in achieving certain ends" (p.34). Van and Field (1990) point out and argue that the leadership role requires attention to individuals and organizations. Essentially, we see him (the leader) filling the gap between subordinate desires and abilities on one hand and organizational goals and requirements on the other. In essence, when the gap is filled, there should be satisfied subordinates in a high performance organization. Conger (1992) further goes into depth and stated that "Leaders are individuals who establish direction for a working group of individuals who gain commitment from this group of members to this direction and who then motivate these members to achieve the direction's outcomes" (p.18). Leadership may be broadly defined (Encyclopedia of Social Sciences, 1999) as "the relationship between an individual and a group built around some common interest and behaving in a manner directed or determined by him" (p.46). (Good, 1973) Leadership is "the ability and readiness to inspire, guide, direct, or manage others, the role of interpreter for the interest and objectives of a group, the group recognizing and accepting the interpreter as spokesman"(p.18). A "leader", Apps (1994) for instance, is ordinarily understood to be a prominent and active person. All leaders together are the "leadership" Asbaugh and Kasten (1995) that viewed in relation to the individual. Leadership is not an attribute of the personality but a quality of his role within a particular or specified social system.

Stogdill (1974) came to the following conclusion:

"A person does not become a leader by virtue of some combination of traits but the pattern of personal characteristics of the leader must bear some relationship to the characteristics, activities, and goals of the followers. Thus, leadership must be conceived in terms of the interaction of variables, which are in constant flux and change (p.127)".

Chemers (1997) advises to concentrate on leadership acts rather than on leaders. Cohen (1990) suggests "Leadership is the art of influencing others to their maximum performance to accomplish any task, objective or project" (p.9). The leader affects the group by initiating action, facilitating communication, establishing structure and implementing his own philosophy in the manner in which he leads.

According to Combs, Miser and Whitaker (1999) leaders show responsibility and authority while planning, initiating, managing, delegating, coordinating, decision-making, communicating and evaluating. In solving any particular problem, a principal might use one or several of these acts of leadership.

Hemphill (1964) makes useful and important distinction between behavior of an administrator, an administrative behavior and leadership behavior. The first category is global, incorporating all acts performed on the job and off the job by the administrator. This category is too broad to explain. The other two deserve elucidation. Leadership involves, among other dimensions, initiation of procedure or creation of structure to achieve or to change the goals of an organization. In contrast to leadership, administration focuses on utilizing already available structure to achieve goals of organization. Crawford, Kydd and Riches (1997) say that the leader is circumscribed by the current state of affairs. The administrative behavior and the leadership behavior generate from the principals of the schools. 


\section{Macrothink}

The functions of a leader that have been identified by Mackenzie and Corey (1954) are summarized as: (i) cooperating in the identification of common goals; (ii) motivating individual, making decision, taking action, and evaluating the work of the group; (iii) developing favorable and healthy climate for individual and group effort: (iv) guiding individuals and group to make them self-dependent and competent; (v) preparing individual duals and group for immediate and long-range activities; (vi) becoming a friend, philosopher and guide from time to time; (vii) co-coordinating the efforts of others; and (viii) carrying out effectively any responsibilities for action that have been accepted and expected of him by the group.

Some generalizations drawn by some of the students of leadership are worth noting. To avoid overlapping, the generalizations made by Campbell, Corbally and Ramseyer (1963); Conger and Kanungo (1988); Deal and Peterson (1999); and Davies (2005) are summarized as below. This is done to enrich the clarification of the concept of leadership. It also crystallizes and summarizes some points in the concept of leadership.

i. Leadership is the product of interaction between leader and followers, and not that of status or position.

ii. Leadership cannot be pre-structured. It is always circumscribed by interactional patterns in the group, structure and group goals.

iii. A leader in one situation may not be effective in another situation.

iv. Whether a person is or is not a leader in a group depends on how he is perceived by the group.

v. The way a leader perceives his role determines his actions.

vi. Leadership manifests positive sentiments towards the group-activity and towards the persons in a group.

vii. Leadership may be autocratic, democratic but never laissez-faire.

viii. Leadership protects the standard of behavior (norms) of the individuals in a group.

ix. Persons perceived by others as leaders are adorned with some authority to take decisions and actions for the group.

x. Leadership is not a monopoly of one person. All group members have leadership potential to some degree.

xi. The effectiveness of leader behavior is measure in terms of mutuality of goals, productivity in the achievement of these goals and the maintenance of group solidarity.

xii. Leadership is directed toward modifying and changing the behavior of members. Changes in people's behavior are manifestations of changes in their goals, perceptions, understandings, insights, values, beliefs, motivations, interrelationships, habits and skills. To bring about change in the behavior of people, leadership behavior alters one 
or more of these factors.

xiii. The quality of an organization is often evaluated by the perceived quality of leadership.

xiv. The qualities of leader's ideas are often a more powerful force than his external behavior.

Xv. Institutional changes are dependent upon the organization of changes in individuals. Leadership behavior in formal organizations resorts to grouping, programming and rearranging relationships.

xvi. Leadership behavior very often creates imbalance in a group with a view to moving group in a desired direction. Here, leader employs varieties of techniques without becoming neutral.

From the above expositions of the functions, tasks and results of leadership, it

It can be said with reasonable certainty that the evaluative study of leadership behavior is the most scientific approach to understand leadership.

\subsection{Historical, Philosophical, Sociological and Behavioral Foundations of Leadership}

Leadership has occupied the mind of human beings, from the time immemorial. Much of the record of human experience, which the civilized world has stored and preserved, concerns leadership. Man makes the impossible task possible. Much depends on the nature of the leader. Early writers have devoted considerable space and energy on problems of leadership. Plato for instance in his "Republic" give considerable attention to the characteristics of the ideal and just ruler the men "Philosopher King". Machiavelli's 'The Prince' presented detailed strategies on how a leader could gain and maintain power over others. Lord Krishna's 'Sanjay' provided demonstrable traits as a leader of the Pandavas after getting proper motivation from his friend, philosopher and guide. Philosophical foundation of leadership explains the traits or qualities of a leader. Persons who are born with certain traits, qualities or characteristics are fit for their leadership roles. Among the many, some of the outstanding personal traits that qualify a person to be a leader are intelligence, creative imagination, emotional stability and steadfastness. The implication of this thesis is that persons possessing these qualities should be sought out and selected to perform leadership roles. Leadership is always found in the same kind of group and the leader functions essentially in relationship to his followers. Sociologists lay more emphasis on the characteristics of a group rather than on the leader who leads the group. It is an interactive process between members of the group, specifically and interaction between the leader and the rest of the group. Behavioral foundations emphasize observed behaviors of leaders in specific situations. Behavioral scientists accept that the people, who are involved in leadership, do possess some personal inherited trades and they function in a particular situation. They reject the plain statements about causal relationship. Behavior of a leader may differ from situation to situation. 


\subsection{Approaches to the Study of Leadership}

The success of a leader in getting the work done through others depends to a great extent on his knowledge of the principles, concepts and techniques of human relations and his ability to apply knowledge in proper perspective and spirit. The following brief review of some of the approaches that have been used to investigate leadership and to explain its nature will help in exploring this area.

\subsection{The Trait, The Type, The Situational and The Behavioral Approaches}

According to Tead (1965), there are ten qualities that are essential for effective leadership: physical and mental energy, a sense of purpose and direction, enthusiasm, friendliness and action, integrity, technical mastery, decisiveness, intelligence, teaching skill and faith. Barnard (1938), on the other hand, lists the following traits or qualities: physique, skills, technology, perception, knowledge, memory, imagination, determination, persistence, endurance, and courage.

"The Type" approach is another basic attempt to explain the nature of leadership. The research workers following this line of thought have concluded that there are essentially four types of leaders:
a. The dictatorial leader;
b. The autocratic leader;
c. The democratic leader; and
d. The laissez-faire leader.

The situational approach to leadership acknowledges the importance of the characteristics of the group and the style of leadership. Various types of situations determine the type or style of leadership that is effective. Situational variables that became special areas of study in situation research were organizational climate, the task or type of assignment perfumed by the group, degree of formal authority or power. The leadership situation included three components, listed in order of importance: (1) Leader-member relations-degree to which group members support, respect, and like the group leader, (2) task structure - the degree to which group tasks are spelled out; (3) position power-power vested by the organization in the leader's position, or the degree to which the position enables the leader to get the group to accept his or her leadership.

Fiedler (1973) classified leaders as either task-Oriented or human-relations Oriented, as determined by the leader's score on a personality measure, called The Least Preferred Co-Worker Scale (LPC).

Behavioral approach is the result of underlying defects of the above approaches. This approach to the study of leadership concentrates on observed behavior. It may, however, not be possible to measure all the behaviors of an individual. Human natures as well as human behavior are mysterious phenomena. There is a continuous interaction between the behavior of the group and the behavior of the leader. They are intrinsically interwoven. 


\section{Macrothink}

Their behavior is determined by the expectations imposed by the institution. The behavior of the principal of a high school is greatly influence by the attitude of the school management and the behavior of teachers under him and vice versa. And his behavior as well as those of his colleagues may be governed, to a varying extent, by Departmental regulations, and the pressures from the community and management.

\subsection{The Styles of Leadership}

As stated earlier in the previous section, 'leadership' and 'follower ship' are relative terms. The growth and development of the institution depends on the leadership-follower ship's relationship. Styles of leadership are based on the relations between leaders and followers. Lipham (1964) has identified three different leadership-followership styles viz., (1) normative; (2) personal; and (3) transactional.

\subsubsection{The Normative Style}

According to this style, leader looks upon his role, i.e. what he is expected to do to achieve the goals of institutions rather than to the requirements of the individual? Every institution (South worth, 2004) has some rules to follow which leads towards better achievement. A leader also has to follow those rules as he prescribed for others to follow.

\subsubsection{The Personal style}

Here the emphasis is on the personal dimensions of the behavior of individuals rather than on the requirements of the institution. Here, the man rather than machine is more important. It is based on the philosophy that better results will be attained if each person in the organization is given the opportunity to contribute to the fullest extent of his capacity towards the growth and development of the institution (Collard and Reynolds, 2005).

\subsubsection{The Transactional Style}

This style is shaped according to situation. Under one set or circumstances, it will attain one shape and under another set of circumstances it will take another shape. It takes intermediate position between 'normative' and 'personal' styles. This institution and the individual, both are taken into account. Leader has to find compromise between these two. He has to work within the limitations of an institution and within the limitations of individuals. This task is not easy. Apps, 1994) have also observed that, though most desirable this style is vague or hazy and not well defined.

\subsection{Theories of Leadership}

There are several approaches to the study of leadership, but here it will be classified into three categories: (1) trait, (2) behavioral, and (3) situational theories, and conclude with an integrated model of leadership style. There is some obvious overlapping among the categories and among the various models and approaches within each category. The following is the most important than other theories. 


\subsubsection{The Fiedler Version of Contingency Theory}

Looking back over the sum of the LBDQ research, Fiedler, citing Korman's (1964) review of the available literature, points out the inability to consistently relate specific leader behaviors to effective group performance and group satisfaction. "Why these behaviors (consideration and initiating structure) do not predict or correlate with group performance represents a major theoretical problem. One clue that might assist us toward a satisfactory explanation is the finding that situational factors and certain personality attributes interact in determining leadership effectiveness. Could similar interactions determine leader behaviors?"(p.25) Fiedler's response is a definite yes. Much of his energy and that of the research community as well, have gone to supporting this contention.

Contingency variables as situational variables influence the relationship between environmental demands and the organization's responses to those demands. Contingency theories of leadership treat contingency variables (Garcia, 1980) as those variables that influence the relationship between leadership styles and subordinate responses to those styles. By leadership style or personality style Fiedler means "a transsituational mode of relating and interacting with others" (p.55). When building a contingency theory of leadership, the following interlocking factors must be accounted for. (a) some dimension of a leadership style (b) a situational variable and (c) a measure of effectiveness of leader behavior.

The relationship between (a) and (c), then is moderated in a predictable way by b. Perhaps one of the most important implications of the contingency theory of leadership is that in a large measure specific condition within the organization are as responsible for the success or failure of the leader. According to this assumption, in the organization a variety of problematic situations confront the leadership setting. The leader is in danger of floundering if he does not possess the appropriate leadership style to treat the situational character of the problem. Tannenbaum et al. provide a useful definition that emphasizes the situational nature of leadership. They define leadership as "interpersonal influence exercised in a situation and directed, through the communication process toward the attainment of a specified goal or goals.

\subsubsection{Task-Motivated/Relationship-Motivated}

Two basic assumptions are implicit in Fiedler's thinking. First, the contingency model maintains personality attributes that are stable and enduring underlie the motivational system of the leader. The changes that do occur in personality are gradual and relatively small; barring major upsets in the leader's life. The leader has either a relationship-motivated or a task-motivated leadership style. Second, the three most important situational variables interacting with a leadership style are (1) leader-member rations, (2) the task structure, and (3) the formal power position. All three conditions have an impact on the degree of control of the leader.

The relationship-motivated leader strives to maintain good interpersonal relationships with his subordinates. Under conditions of uncertainty and anxiety, this leader will seek support and closer relations with his subordinates. When the leader has the close support of 
subordinates and feels quite secure in the work situation, he will pursue the esteem and admiration of significant others. When task performance is essential to win the esteem and admiration of superiors, the relationship-Oriented leader will strive in this direction-even if it sometimes detracts from the close interpersonal relationships with subordinates.

The task-motivated leader, on the other hand, obtains personal satisfaction from accomplishing objectives in an effective and efficient manner. When this leader is placed in an uncertain and anxiety-provoking situation, he will place emphasis on giving structure and direction to events so that the task can be accomplished. Under other conditions, however, when conditions surrounding the task are under control and his influence is high, the task-Oriented leader will relax and respond to the need for consideration of the subordinates' feelings. "In other words," Fiedler (1978) writes, "business before pleasure, but business with pleasure whenever possible" (p.25).

Reflecting on the data from his numerous studies, Fiedler (1978) writes:

The basic findings of the Contingency Model are that task-motivated leaders perform generally best in very "favorable" situations. i.e., either under conditions, in which their power, control and influence are very high or, conversely, where uncertainty is very low or where the situation is unfavorable, where they have lower power, control and influence. Relationship-motivated leaders tend to perform best in situations in which they have moderate power, control and influence (p.38).

Under situations of moderate favorableness, the relationship-motivated leader tends to be more effective in obtaining optimal group performance. This is because in these task situations the leader must be diplomatic and draw upon the creativity and cooperation of the members. When the task situation is very favorable (when the leader is well liked, the task structured, high formal power exists), nondirective behavior and an orientation toward consultation is neither appropriate nor beneficial.

In terms of the model, it is not accurate to speak of a leader as being good or bad, because a leader may perform well; less than one set of conditions and not under another. Like all new attempts to advance some dimension of the social sciences, Fred Fiedler's contingency theory of leadership is highly controversial. In the evolutionary process of a new theory statistical gunfights inevitably break out between the researchers who are trying to establish the validity of his theory and the academicians who review the literature. Fiedler's contingency theory of leadership has received impressive support in the research literature. The model has also been vigorously challenged in terms of methodological rigor and theoretical adequacy. Robbins (1983) summarizes weaknesses in the models that have been identified by several researchers. First, in contingency theory the variables are rather difficult to measure. It is not easy to assess the level of relationship of leader and follower and how much power a leader enjoys. Second, the model gives little attention to the characteristics of the subordinates. Third, no attention is given to varying technical competencies of the leader or the sub-ordinates. The model assumes that both the leader and subordinates have adequate technical competence. Fourth, the correlations Fiedler presents in defense of the model are often low and statistically non-significant. Finally, the LPC instrument is open to question. 


\section{MInstitute ${ }^{\text {Mink }}$}

The background rationale underlying this instrument has not been grasped well as shown by different studies that stores are not stable. Among other complexities another problem with contingency theory of leadership is suggested by Chemers and Rice (1974), who point out that there are other situational variables (beyond the basic three) that can be important in determining the favorableness of the leadership situation; for example, stress, linguistic or cultural heterogeneity, organizational climate, and level of training.

Finally, Fiedler (1978) writes: The problem at issue is whether (a) the tendency to behave in a considerate, employee-centered manner is an attribute of the leader's personality, and therefore properly considered to be his leadership style; or (b) whether the leader's personality and the situation interact, and the person who is considerate under one condition tends to be relatively less considerate under other conditions. If the latter is the case, it will have major implications for current leadership theory (p.67). Whatever the final disposition of Fiedler's model becomes, his work has made it clear that an adequate analysis of leadership calls not only for a study of the leader, but also for a study of situations.

\section{Research Methodology}

\subsection{Procedure of the Study}

It is correlational study in nature. The main objective of this study was to find out impact of educational leadership behavior (both relation-oriented and task-oriented) and demographics on institutional performance. Therefore, the data regarding relation-oriented behavior [interpersonal skills, integrity, persuasiveness, sensitivity and Group Leadership], task-oriented behavior [efficiency in planning \& organizing, time management, personnel management, delegation of powers and programmed evaluation for the effective intuition performance] and Leadership Demographics (Attributes viz. age experience, academic \& professional qualification and training received and Situational Factors viz. students' achievement level, enrollment, administrative tasks done (if leader is EDO [Education] or DEO [SE] M/F, location (Rural/Urban) and physical facilities) will be collected to measure institutional performance.

For the purpose of measuring leadership behavior, following three tools were developed for the study after going through the related literature for collection of information from the relevant sample of population.

\section{Leader Behavior Description Questionnaire (LBDQ)}

2. Institutional Performance Questionnaire (IPQ)

3. Leadership Demographics Checklist (LDC)

The above mentioned research tools was tried out with a group of 20 heads of Higher Secondary Schools, 10 heads of degree colleges, 05 heads of professional colleges, 05 EDOs (Education) and 05 DEOs who will assemble in different INSET and meetings at Directorate of Staff Development (DSD), Punjab, Lahore. They were requested to amend the research tools in format and language and make them simple and understandable. Accordingly the research tools were revised by incorporating their suggestions. Final version of the research 


\section{Macrothink}

Journal of Public Administration and Governance ISSN 2161-7104 2012, Vol. 2, No. 1

tools were developed and distributed to collect information from the relevant sample of population.

\subsection{Population}

All the educational administrators working in educational institutions-school, college, district and provincial level formed the population for this study.

\subsection{Accessible Population}

The accessible population of the study was composed of layers (strata) of different types of individual educational units, which is as under:-

\subsection{Strata No. Strata Description}

Strata 1 Heads and their Subordinates of all Higher Secondary Schools in the Punjab

Strata 2 Heads and their Subordinates of all Degree Colleges in the Punjab

Strata 3 Heads and their Subordinates of all Govt. College of Education in the Punjab

Strata 4 EDOs (Education) in the Punjab and their Subordinate

Strata 5 DEOs (SE) in the Punjab and their Subordinate

The population of study was consisted on Principals of Higher Secondary Schools, Degree Colleges and Colleges of Education, district educational officers (DEOs), executive district officers (EDOs), and their subordinates respectively.

\subsection{Sampling Design of the Study}

There are various strata in educational scenario. Researcher selected clusters from five strata and fix participants' quota for study from these clusters. Such selection of sample is called stratified cluster quota sampling. For this research study, stratified cluster quota sampling design has been followed. The percentage of selected clusters from each stratum is as:

$125 \%$ of higher secondary schools

$2 \quad 25 \%$ of degree colleges

$3100 \%$ Government Colleges of Education

$450 \%$ of all the EDOs (Education)

$550 \%$ of all the DEOs (Education) 


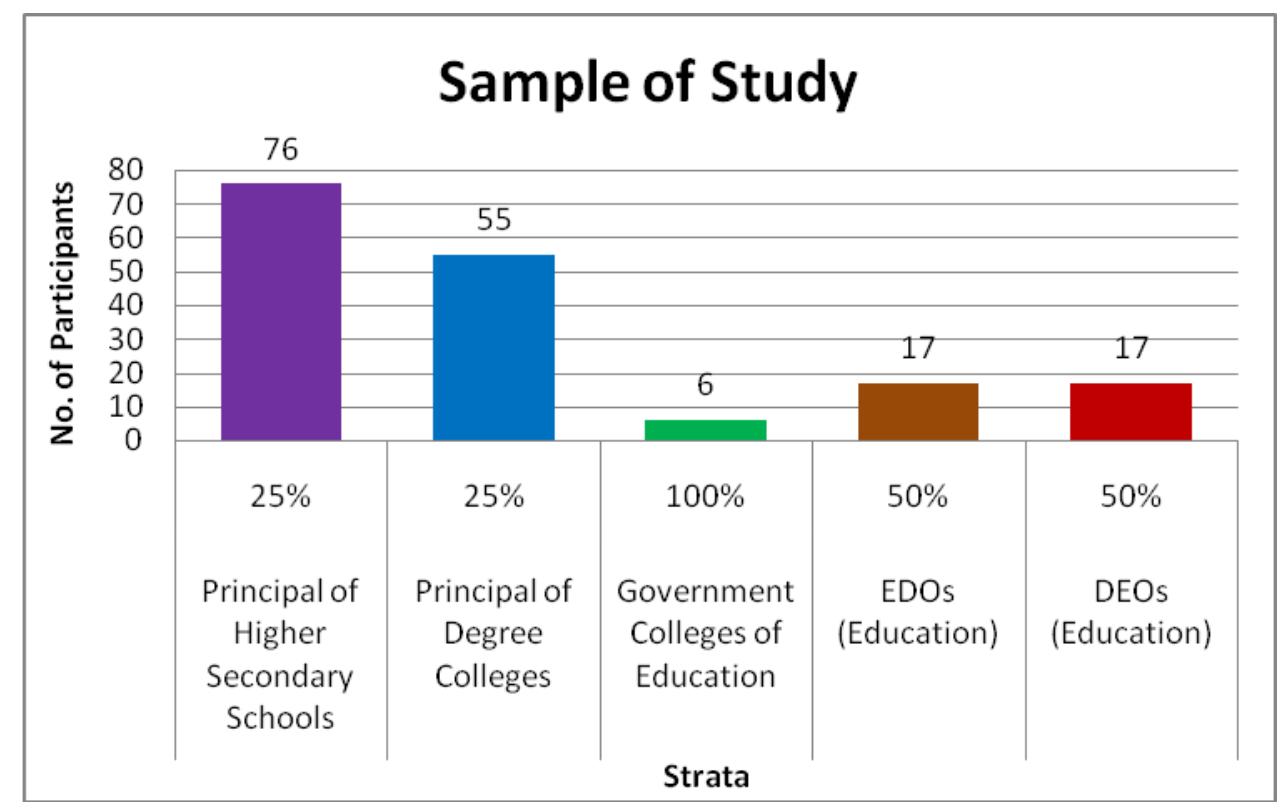

After identification of clusters from each stratum, head and eight subordinates from each cluster were included in the sample.

\subsection{Instrumentation}

Three following questionnaires were developed for the study after going through the related literature.

Leader Behavior Description Questionnaire (LBDQ)

Institution Performance Questionnaire (IPQ)

Leadership Demographics (Attributes + Situational Factors) Checklist (LDC)

The 30 items of LBDQ were aligned, with some cultural modification, with the instruments of Leader Behavior Description Questionnaire developed by Ohio and Michigan States Leadership Research Programme (Hemphill \& Coons, 1950), the Supervisory Behavior Description (SBD) (Fleishman, 1953); the Leadership Orientation Questionnaire (LOQ) (Stodgill, 1963).

Institution Performance Questionnaire (IPQ) was developed to serve as tool for diagnosing how a teacher/staff, being a subordinate, perceives his head towards achieving national objectives as reflected in the national documents. The instrument containing 25 items were developed for measuring an important variable of leadership effectiveness, institutional effectiveness and to quantify the institutional heads' behavior in terms of achieving for national objective. The Leadership Demographic (Attributes + Situational factors) Checklist (LDC) was developed to find out relationship about heads' attributes and situational factors towards the institutional leadership effectiveness.

\subsection{Validation of Instruments}

Developed instruments were sent to five faculty members of five educational research 
intuitions-University of Sargodha, AIOU, NUMAL, Bahawalpur University and GC University of Lahore, and departments of psychology of University of the Punjab Lahore and Quid-e-University Islamabad. All the items were validated by these members. Recommendations of departments of psychology were incorporated. The 30 items if LBDQ were tried out with a group of 20 heads of higher secondary schools, 10 heads of degree colleges, 10 EDO (Education) and 10 DEO assembled in different INSET and meetings at Directorate of Staff Development, Punjab, Lahore. They were requested to respond and give their feedback regarding to format and language of the instruments. Accordingly theses questionnaires were revised by incorporating their suggestions. Then the final version and draft of questionnaires were developed.

\subsection{Instrument Administration and Data Collection}

The data collection activity was very difficult and monotonous one for the researcher because of different types of layers (strata) of individual educational units. The researcher had to visit five different samples educational institutions time and again for the filling up of 855 questionnaires form the educational leaders and subordinates/teaching staff. To overcome this difficulty, Additional Secretary (Schools), Govt. of the Punjab, Education Department, Civil Secretariat, Lahore was requested for issuing a direction to all the individual educational units as mentioned in the population for filling up of questionnaires and full cooperation. The Additional Secretary (Schools) very graciously acceded to the request and issued a letter indicating therein the request of researcher and mentioning the names of different questionnaires. As a result of it the cooperation from the field was highly commendable. Properly filled in questionnaires were returned within stipulated time. However, the researcher found some difficulties in collection of properly filled in questionnaires from few EDO's and heads of Govt. College of Education. After some diligent and personal efforts it was possible to collect the required number of filled in questionnaires (data) from the respective respondents. In this way required data was collected from all the layers (strata) of individual educational units.

\subsection{Analysis and Interpretation of Data}

The variables of the study were formed continuous in quantifiable terms at interval scale of measurement. T-test and correlations was used to see the relationships and their significance.

Table: 1

\begin{tabular}{|c|c|c|c|c|c|c|}
\hline \multirow[t]{2}{*}{ Performance } & \multirow[t]{2}{*}{ Category } & \multirow[t]{2}{*}{ Strata } & \multirow[t]{2}{*}{ Count } & \multicolumn{2}{|c|}{ Description } & \multirow{2}{*}{$\begin{array}{l}\text { Sig. } \\
\text { Level }\end{array}$} \\
\hline & & & & Mean & SD & \\
\hline \multirow[t]{7}{*}{ Educational Leaders vs their age } & \multirow{4}{*}{ Below 45 years } & GHSS & 376 & 121.14 & 15.771 & \multirow{7}{*}{0.05} \\
\hline & & GDC & 217 & 118.59 & 19.936 & \\
\hline & & DEO & 48 & 118.96 & 18.785 & \\
\hline & & EDO & 40 & 114.50 & 16.04 & \\
\hline & \multirow[b]{3}{*}{ above 45 years } & GHSS & 175 & 122.56 & 15.509 & \\
\hline & & GDC & 168 & 131.64 & 14.613 & \\
\hline & & GCE & 48 & 125.27 & 29.29 & \\
\hline
\end{tabular}




\begin{tabular}{|c|c|c|c|c|c|c|}
\hline & & DEO & 80 & 105.43 & 32.395 & \\
\hline & & EDO & 88 & 111.23 & 14.997 & \\
\hline Educational Leaders vs their & (MA/MSc.) & GDC & 352 & 123.60 & 19.277 & \multirow{10}{*}{0.05} \\
\hline Professional cum Academic & \multirow{4}{*}{$\begin{array}{l}\text { (MA/MSc, } \\
\text { BEd/MEd) }\end{array}$} & GHSS & 488 & 120.21 & 15.288 & \\
\hline \multirow[t]{8}{*}{ Qualification } & & GCE & 32 & 116.19 & 31.561 & \\
\hline & & DEO & 88 & 103.01 & 29.542 & \\
\hline & & EDO & 104 & 111.96 & 15.260 & \\
\hline & \multirow{5}{*}{ (MPhil/PhD) } & GHSS & 64 & 132.19 & 14.604 & \\
\hline & & GDC & 32 & 131.81 & 12.977 & \\
\hline & & GCE & 16 & 143.44 & 10.073 & \\
\hline & & DEO & 40 & 126.98 & 18.441 & \\
\hline & & EDO & 24 & 113.50 & 15.970 & \\
\hline \multirow{9}{*}{$\begin{array}{c}\text { Educational Leaders vs their } \\
\text { Management training }\end{array}$} & \multirow{4}{*}{ Courses Attended } & GHSS & 376 & 121.86 & 15.77 & \multirow{9}{*}{0.05} \\
\hline & & GDC & 217 & 128.98 & 12.54 & \\
\hline & & DEO & 48 & 110.53 & 15.34 & \\
\hline & & DEO & 40 & 112.25 & 19.977 & \\
\hline & \multirow{5}{*}{ No Course Attended } & GHSS & 175 & 120.24 & 22.921 & \\
\hline & & GDC & 168 & 122.14 & 15.134 & \\
\hline & & GCE & 48 & 125.27 & 17.277 & \\
\hline & & DEO & 80 & 110.43 & 19.917 & \\
\hline & & EDO & 88 & 112.25 & 16.942 & \\
\hline \multirow{9}{*}{$\begin{array}{l}\text { Educational Leaders vs No. of } \\
\text { employees supervised by them }\end{array}$} & \multirow{4}{*}{ up to 25 employees } & GHSS & 64 & 125.08 & 14.776 & \multirow{9}{*}{0.05} \\
\hline & & GDC & 80 & 128.57 & 13.752 & \\
\hline & & DEO & 56 & 97.05 & 27.37 & \\
\hline & & EDO & 96 & 112.25 & 15.363 & \\
\hline & \multirow{5}{*}{$\begin{array}{l}\text { more than } 25 \\
\text { employees }\end{array}$} & GHSS & 488 & 121.14 & 15.746 & \\
\hline & & GDC & 304 & 123.15 & 19.969 & \\
\hline & & GCE & 48 & 125.27 & 29.29 & \\
\hline & & DEO & 72 & 120.96 & 25.393 & \\
\hline & & EDO & 32 & 112.25 & 15.527 & \\
\hline \multirow[t]{6}{*}{ Educational Leaders vs their Results } & \multirow{3}{*}{$\begin{array}{c}\text { Above } \\
\text { Board/University }\end{array}$} & GHSS & 193 & 124.15 & 14.845 & \multirow{6}{*}{0.05} \\
\hline & & GDC & 224 & 126.32 & 17.325 & \\
\hline & & GCE & 32 & 119.16 & 33.256 & \\
\hline & \multirow{3}{*}{$\begin{array}{c}\text { Below } \\
\text { Board/University }\end{array}$} & GHSS & 359 & 120.23 & 15.955 & \\
\hline & & GDC & 160 & 121.43 & 20.751 & \\
\hline & & GCE & 16 & 137.50 & 12.775 & \\
\hline \multirow{4}{*}{$\begin{array}{l}\text { Educational Leaders vs No. of } \\
\text { institutions they visited }\end{array}$} & \multirow{2}{*}{ Institutions Visited } & DEO & 96 & 110.19 & 27.828 & \multirow{4}{*}{0.05} \\
\hline & & EDO & 104 & 112.54 & 15.448 & \\
\hline & \multirow{2}{*}{$\begin{array}{l}\text { Institutions Not } \\
\text { Visited }\end{array}$} & DEO & 32 & 111.44 & 31.815 & \\
\hline & & EDO & 24 & 111.00 & 15.137 & \\
\hline \multirow[t]{2}{*}{ Educational Leaders vs PC-1 prepared } & \multirow{2}{*}{ PC-1 prepared } & DEO & 104 & 113.16 & 27.859 & \multirow{2}{*}{0.05} \\
\hline & & EDO & 104 & 112.54 & 15.448 & \\
\hline
\end{tabular}




\begin{tabular}{|l|c|c|c|c|c|c|}
\hline \multirow{2}{*}{ PC-1 not prepared } & DEO & 24 & 98.96 & 30.295 & \\
\cline { 3 - 6 } & & EDO & 24 & 111.00 & 15.137 & \\
\hline
\end{tabular}




\section{Discussion}

Data analyses represented in Table No. 1 explores that:

- Although performance of educational leaders of above or below 45 years is almost same but performance of heads of Government Degree Colleges (GDC) is significantly better than all other educational leaders.

- Educational leaders having higher educational academic qualifications are performing well than others. It may be interpret as that higher education especially research work made them handworker that reflect from their performance.

- Those educational leaders who got management training show significantly better performance than other. It is concluded that management courses builds the managerial capacity of the leaders.

- Performance of the education leaders is directly proportional to the number of employees working under their administrative control.

- There are only six colleges of education in the Punjab so even their results are below university but their performance is significantly better than all other educational leaders.

- Executive District Offers of Education are bound for compulsory and surprise visits of school under their administrative control. Graph explores that the performance of those EDOs visiting institutions is significantly better than EDOs and District Education Officers (DEO) not visiting any institution during academic year.

- District education authorities (EDOs and DEOs) that involved in the preparation of project commissions (PCs) show better performance than other educational authorities those did not involve in the preparation of PCs.

The judgment of the subordinates/teaching staff of educational leaders about their Relation Oriented \& Task Oriented Behavior and their leadership effectiveness on Intuition Performance is very positive which indicates that leaders are performing their duties with entire satisfaction to achieve the organizational objectives. In this connection this study affirms that those educational leaders who have good positive scores in Relation Oriented \& Task Oriented Behavior dimension have been positively amended by their subordinates as well. This study supports researches done by Fleishman \& Simmons, (1970); Likert, (1961) and Stogdill, (1974) in the area of leadership behavior and effectiveness which make a positive correlation both Relation Oriented \& Task-Oriented Behavior dimension directly to the leadership effectiveness. Although these two traditional leadership behavior (Relation \& Task-Oriented Behavior) dimensions have good responding correlation with leadership effectiveness on Institutional Performance but it does not mean to infer that only the leadership effectiveness dimensions is the sole factor for achieving the organizational objectives. The evidence from this research seems to support Brown's (1967), Halpin's (1966), Leverette's (1984), Zaidi's (1989) and Mehmood's (1995) contentions that both consideration (Relation's) and initiating (task) structures are important behavior for 
educational leaders.

The present study seems to support Khan (1994) findings that both the behavior (Relation and Task Oriented) reflect high on relationship. This mean that educational leaders of this study tend to remain high on Relation Oriented Behavior coupled with Tasks-Oriented Behavior. The research evidence also seems to support Burns (1994), Clark (1981) and Sims \& Manz (1984) who have also identified that Relation-Oriented and Task-Oriented Behavior have high correlation coefficient in different settings.

This study, however, disagrees with Evenson (1959), Halpin (1955), Levine (1990), Lipham (1981), and Newmann (1989) who found that educational leaders generally value consideration (Relation-Oriented, Interpersonal Skills, Integrity, Sensitivity Persuasiveness and Group Leadership) more highly that structure (Task-Oriented, Planning, Organizing, Flexibility \& Adaptability, Time Management, Personnel Management, Delegation of Power and Programme evaluation) furthermore, diverse results of his study may be varied due to different situational contingencies and group dimension. Yet these environmental factors have an important impact on educational leadership behavior.

Fraser (1986), Lipham (1981), Richardson \& Skinner (1990) and Rosenholtz (1989) affirm that educational leaders perform their duties effectively with a high concern for both cohesive social relation (Relation-Oriented) and task accomplishments (Task-Oriented Behavior) in this regard this study, suggests that a balance of both emotionally supportive human relationship, (Relation-Oriented Behavior) and high instrumental norms (Task-Oriented Behavior) can create a high positive correlation coefficient to achieve educational goals.

This study strongly suggests strong relationship (both Relation and Task Oriented Behavior) on the part of educational leaders on Students' Achievement Level whereas contrary to this Dwyer (1984), Levine (1990), and Lipham (1981) have been strong proponents that human relationship interpersonal training should become a mandatory component of the in-service training of educational leaders in staff development and teacher education institutions. Apparently, the emphasis of current literature in the area on Relation Oriented Behavior is certain to become even stronger in further enhancing students, achievements level but this study explored that emphases should be for task oriented behavior of educational leaders.

The findings of study regarding leadership Demographics (Attributes \& Situational Factors) are of mixed type. This study notes that educational leaders' length of experience (more than ten years) of educational leaders, management courses attended, planning skills (preparation of PC-I), age (above 45 years), strength of employees (more than 25), and educational qualification (MPhil/PhD), have significant positive effect on the performance of their respective institutions. Educational leaders' institutional visits, results (above bard/university), and intuitional under their control have directly negative effect on institutional performance.

Given the findings in this study, a relatively straight forward profile of educational leaders on institutional performance emerges. An effective educational leader according to this study is one who has style-Oriented Behavior which reflects the behavior of the leader as high on 
relationship i.e. high on consideration, better with professional qualification, interaction with Subordinates/teaching staff enjoyable academic freedom that acts as catalyst in the use of potential of the staff for better instructional efficiency. Above all, it all develops cohesiveness among the staff for fulfilling the goals of the institutions and has highly personal job relationships.

\section{Findings}

Principal findings and conclusion in forthcoming paragraphs represent most significant results of under reference study. Conclusions of this study are strictly matched with purpose and delimitations. All five hypotheses were accepted. Objectives of study were achieved. Data which underline nature of relationship and significance of educational leaders on institutional performance are reported under.

1. There is significant difference between the institutional performance of the leaders having attended management courses and those who not attended management courses. additionally The performance of heads of GHSSs is significantly better in both groups who attended and who not attended management courses, whereas the EDOs and DEOs appears to be low performer in term of showing institutional performance.

2. There is significant difference between the institutional performance of the leaders having age below 45 years and above 45 years. The educational leaders who are below 45 years age has shown better performance and out of these, principals of GHSS appear to be at top of the performance whereas EDOs are the least performer. On the other hand out of the mature and experienced educational leadership squad principals of GDCs have shown better performance than all other heads of institutions whereas DEOs have shown least performance in term of institutional performance.

3. There is significant difference between the institutional performance of the leaders having experience below ten years and those having more than ten years. Study explored by the analysis that principals of GHSS have shown better performance than others leaders among the group who have less than ten years experience whereas principals of GCE are the least performer in this group. On the other hand in other group principals of GDCs are top performer among the leaders who have more than ten years experience with mean score (118). It is also pertinent to mention that principals of GDCs are also the top performer among both groups.

4. There is significant difference between the institutional performance of the leaders having above board/university result and those having below board/university result. Study explored that Principals of GCEs has shown significantly better performance among all other group members who has below board result in board/university. This is very interesting finding in a sense that the educational leaders whose institutions have below board results have been rated better by their subordinates. It means they may be favorite of their subordinates as they have lose control on institutions that resultantly showing low performance. On the other hand the other group with 
educational leaders having above board results, the principals of GDCs have shown better results where as principals of GCEs has shown least performance.

5. There is significant difference between the institutional performance of the leaders having up to 25 employees under their administrative control and those more than 25 employees. Study showed that leaders who have more than 25 employees under their administrative control, the principals of GHSS and GDC have shown better performance than other leaders whereas principals of GCEs have shown least performance in term of institutional performance.

6. There is significant difference between the institutional performance of the leaders having M.A/M.Sc. Qualification and those having higher degree of M.Phil and PhD. Study explored that academic qualification of head of institution may have positive impact on the overall performance of the institution. Within strata leaders who have shown better performance, principals of the GCEs have shown the better performance and the least performer among them are the EDOs of districts.

7. There is no significant difference between the institutional performance of the leaders who visited institutions under their control and who did not visited. Similarly there is significant difference between the institutional performance of the leaders who have institutions under their administrative control and who do not have institutions under their control. Study explored that frequent visits of educational leaders to the institutions under their control do not have any positive impact on the overall performance of the institution.

8. There is significant difference between the institutional performance of the leaders who have prepared PC-1 and submitted and those who did not prepared PC-1.

9. There is no significant correlation between the institutional performance of the leaders who has Relations Oriented Behavior and those who have Task Oriented Behavior. Comparison of both behaviors shows that comparatively correlation between Task Oriented Behavior and institutional performance of the leaders is stronger than the second one even instead of a little difference between their values. Whatsoever are the factors other than educational leaders, the impact of educational leaders on institutional performance cannot be easily ignored.

\section{Conclusions}

The following conclusions are based on the finding derived from the data of the study.

1. From the above study it has been revealed that Task Oriented Behavior \& Relation Oriented Behavior is not independent with each other. They are dependent in a sense that one dimensions of behavior affects the other one. It is also reasonable to conclude that the both behavioral dimensions of educational leaders are not exclusively either Relation Oriented or Task Oriented.

2. The both Relation-Oriented and Task Oriented Behavioral dimensions of educational leaders of the study directly relate to their leadership effectiveness. This evidence also 
suggestion that the strong relationship between these two variables is optional for high leadership effectiveness for achieving the objectives of the organization.

3. The highest degree of strong relationship as the subordinates perceived between the variables of Relation-Oriented Behavior \& Institution Performance and Task-Oriented Behavior \& Institutional Performance has been observed. This relationship strongly effects on the fulfillment of their role for attaining the goals of education as laid down in national documents.

\section{Recommendations}

In modernizing the educational leaders, an important direction may be to identify the styles of leadership that may secure subordinates' satisfaction with supervision and train the educational managers of a particular group more into those leadership behaviors.

\section{References}

Ackerman, R., Donaldson Jr., G.A., \& van der Bogut, R. (1996). Making sense as a school leader. San Francisco: Jossey-Bass.

Ackerman, R.H., \& Maslin-Ostrowski, P. (2002). The wounded leader. Toronto: Jossey-Bass.

Ah Nee-Beeham, J.K.P., \& Cooper, J.E. (1998). Let my spirit soar. Narratives of diverse women in educational leadership. Thousand Oaks, CA: Corwin.

Alison M. Konrad. (2006). Cases in Gender and Diversity in Organizations. Sage Publication.

Andrew J. Harvey and Raymond E. Foster. (2007). Leadership. Texas Hold En Style. Book Surge Publishing.

Anju Mehrotra. (2005). Leadership Styles of Principal. Millat Publications. India.

Apps, J.W. (1994). Leadership for the emerging age. San Francisco: Jossey-Bass.

Asbaugh, C.R., \& Kasten, K.L. (1995). Educational leadership. Case studies for reflective practice. Toronto: Longman

Badaracco, J.L. Jr. (2002). Leading quietly. Boston: Harvard Business School Press.

Bass, B. M. \& Riggo, R. E. (2006). Transformational Leadership (2nd Edition). Mahwah, NJ: Erlbaum.

Bass, B. M. (1985). Leadership and performance beyond expectation. New York: Free Press.

Bass, B. M. (1990). Bass \& Stogdill's handbook of leadership 3rd ed. New York: Free Press.

Bass, B. M. (1990). Bass and Stogdill's handbook of leadership: Theory, research and managerial applications. New York: Free Press

Bass, B. M. (1990). From transactional to transformational leadership: Learning to share the vision. Organizational Dynamics, (Winter): 19-31 
Bass, B.M. (1998). Transformational leadership. Mahwah, NJ: Lawrence Erlbaum Assoc.

Batten, J.D. (1991). Tough-minded leadership. New York: AMACOM.

Begley, P., \& Leonard, P. (1999). The values of Educational Administration. London: Falmer Press.

Bender, P.U. (1997). Leadership from within. Toronto: Stoddart.

Bennis, W. (1989). Why leaders can't lead: The unconscious conspiracy continues. San Francisco: Jossey-Bass.

Bolman, L.G., \& Deal, T.E. (2002). Reframing the path to school leadership. Thousand Oaks, CA: Corwin.

Burns, J.M. (1978). Leadership. New York: Harper \& Row.

Bycio, P., Hackett, R.D. and Allen, J.S. (1995) ‘Further Assessments of Bass’s (1985)

Chemers, M.M. (1997). An integrative theory of leadership. Mahway, NJ: Lawrence Erlbaum Assoc.

Cohen, W. A. (1990). The art of a leader. Englewood Cliffs, New Jersey: Jossey-Bass.

Collard, J. \& Reynolds, C. (Eds.), (2005). Leadership, gender \& culture in education: Male \& female perspectives. Maidenhead, Berkshire, UK: Open University Press.

Collard, J. \& Reynolds, C. (Eds.), (2005).Leadership, gender \& culture in education: Male \& female perspectives. Maidenhead, UK: Open University Press.

Combs, A.W., Miser, A.B., \& Whitaker, K.S. (1999). On becoming a school leader. Alexandria, VA: ASCD

Conceptualization of Transactional and Transformational Leadership', Journal of Applied Psychology, 80(4): 468-78.

Conger, J. A. (1992). Learning to lead. San Francisco: Jossey-Bass.

Conger, J. A., \& Kanungo, R.N. (Eds.). (1988). Charismatic leadership: The illusive factor in organizational effectiveness. San Francisco: Jossey-Bass.

Crawford, M., Kydd, L., \& Riches, C. (1997). Leadership and teams in educational management. Buckingham, UK: Open University Press.

Creighton, T. (2005). Leading from below the surface. A non-traditional approach to school leadership. Thousand Oaks, CA: Corwin Press.

Davies, B. (2005). The essentials of school leadership. Thousand Oaks, CA: Corwin Press.

Davies, B., \& Ellison, L. (1997). School leadership for the 21st century. New York:

Routledge

Deal, T.E. and Kennedy, A.A. (1982) Corporate Cultures: The Rites and Rituals of Corporate Life. Reading, MA: Addison-Wesley. 
Deal, T.E., \& Peterson, K.D. (1999). Shaping the school culture. The heart of leadership. San Francisco: Jossey-Bass.

Denison, D.R. (1990) Corporate Culture and Organisational Effectiveness. New York: Wiley.

Dimmock, C., \& Walker, A. (2005).Educational leadership: Culture and diversity. Thousand Oaks, CA: Sage.

Drucker, P. (1967).The effective excutive. London: Pan books.

Eagly, A.H. and Johnson, B.T. (1990), "Gender and leadership style: a meta-analysis", Psychological Bulletin, Vol. 108 No. 2, pp. 233-256.

Eagly, A.H., Karau, S.J. and Johnson, B.T. (1992), "Gender and leadership style among school principals: a meta-analysis”, Educational Administration Quarterly, Vol. 28 No. 1, pp. 76-102.

Elmore, R. F. (2000, Winter). Building a new structure for school leadership. Washington, DC: The Albert Shanker Institute.

Fred C. Lunenburg and Allan C. Ornstein. (2008). Educational Administration. Conceptual Practices (5th Edition). Thomson Higher Education, Thomson Learning Academic resource Centre. USA.

Fullan, M. (2003). The moral imperative of school leadership. Thousand Oaks, CA: Corwin Press.

Fullan, M. (2005). Leadership \& sustainability. System thinks in action. New York and Toronto: Corwin Press \& Ontario Principals' Council.

Fullan, M. (2005).Leadership \& sustainability. System thinks in action. New York: Corwin Press.

Fullan, M. (2006).Leading in a culture of change. San Francisco: Jossey Bass.

Gerad, H. Seijts. (2006). Cases in Organizational Behavior. Sage Publications.

Goderya-Shaikh, F., Madden, M., \&Saad, I. (2006). Ensuring quality during monitoring of the learning environment of government primary schools achieved through the UEI-PDP for teachers and head teachers. Educational Research and Review, 1(9), 328-336.

Goldberg, M.F. (2000). Profiles of leadership in education. Bloomington, IA: Phi Delta Kappa

Goodland, J.I., Sirontinik, K. and Soder, R. (1990), The Moral Dimensions of Teaching, Berkeley, CA: Jossey Bass.

Gurr, D., Drysdale, L \&Mulford, B. (2005). Successful principal leadership: Australian case studies. Journal of Educational Administration, 43(6), pp. 539-551.

Gurr, D., Drysdale, L and Mulford, B. (2005), "Successful principal leadership: Australian case studies", Journal of Educational Administration, Vol. 43 No. 6, pp. 539-551.

Hallinger, P. (2003). Leading educational change: Reflections on the practice of instructional and transformational leadership. Cambridge Journal of Education, 33(3), 329-51.

Hallinger, P. (2005). Instructional leadership and the school principal: A passing fancy that refused to fade away. Leadership and Policy in Schools, 4(3), 221-39.

Hargreaves, A., \& Fink, D. (2006). Sustainable leadership. Toronto: J. Wiley \& Sons. 


\section{I Macrothink}

Journal of Public Administration and Governance

ISSN 2161-7104

2012, Vol. 2, No. 1

Harris, A. and Muijs, D. (2004), Improving Schools through Teacher Leadership, Oxford University Press, London.

Harris, A., and Chapman, C. (2002), Effective Leadership in Schools Facing Challenging Circumstances, National College for School Leadership (NCSL), Nottingham, UK.

Helgesen, S. (1990). The female advantage: Women's ways of leadership. New York:

Doubleday.

Herr, V. N. C. (1993). Gender-responsible leadership: Detecting bias, implementing interventions. Newbury Park, CA: Sage.

HiTech Criminal Jastice. (2010). What is a Hero? The American Heroes Press.

Holley, V. I. (1995). Relationship of administrative style toward attitudes and implementation of arts education. (CD-ROM) Abstract from: ProQuest File: Dissertation Abstract International Item: 57/01.

Hopkins, D. (2001), School Improvement for Real, Falmer Press, London.

Howell, J.M. and Avolio, B.J. (1993) 'Transformational Leadership, Transactional Leadership, Locus of Control and Support for Innovation: Key Predictors of consolidated-Business-Unit Performance', Journal of Applied Psychology, 78: 891-902.

Hoy, W. \& Miskel, C. (2008). Educational administration: Theory, research, and practice. Boston: McGraw Hill.

Hugh Busher. (2006). Understanding Educational Leadership: People, Power and Culture. Open University Press. UK.

Jacobs, T. O., \& Jaques, E. (1990). Military executive leadership. In K. E. Clark and M. B. Clark (Eds.), Measures of leadership. West Orange, New Jersey: Leadership Library of America, pp 281-295.

Jaques, E., \& Clement, S. D. (1994). Executive leadership: a practical guide to managing complexity. Cambridge, MA: Carson-Hall.

Jeffrey Glanz. (2002). Finding Four Leadership Style. Association for Syervision and Curriculum Development. ASCD, Alexandria, USA.

Kotter, J.P. and Heskett, J.L. (1992) Corporate Culture and Performance. New York: The Free Press.

Kouzes, J. M., \& Posner, B. Z. (1995). The leadership challenge. San Francisco: Jossey-Bass. Leithwood, K. \&Riehl, C. (2003, April). What do we already know about successful school leadership? Paper prepared for the AERA Division A Task Force on Developing Research in Educational Leadership and presented at the annual meeting at the American Educational Research Association, Chicago, IL.

Leithwood, K., and Reil, C. (2003), "What we know about successful school leadership, Brief prepared for the Task Force on Developing Research in Educational Leadership, 
American Educational Research Association, Temple University, Dividion A.

Levine, A. (2005). Educating school leaders. New York: The Education School Project.

Louis, K.S., and Marks, H.M. (1998), "Does professional community affect the classroom?

Teachers' work and student experiences in restructuring schools", American Journal of Education, Vol. 106, pp. 532-575.

MacBeath, J. (Ed.). (1998), Effective School Leadership: Responding to Change, Paul Chapman, London.

Maehr, M. and Midgley, C. (1996), Transforming School Cultures, Westview Press, Boulder, CO.

McEwan, E. (2002). Seven Steps to Effective Instructional Leadership. California: Corwin Press, Inc.

McEwan, E. (2002). Seven steps to effective instructional leadership. California: Corwin.

Mike Wynn. (2008). Rising Through The Ranks: Leadership Tools and Techniques for Law Enforcement. Kaplan Publishing.

Moller, J., Eggen, A., Fuglestad, O. L., Langfeldt, G., Presthus, A., Skrovset, S., Stjernstrom, E. and Vedoy,

G. (2005). Successful school leadership: the Norwegian case. In Jacobson, S. L., C. Day \& K. Leithwood (Eds.), Journal of Educational Administration, The international successful school principalship project (43) 6, $584-594$.

Moller, J., Eggen, A., Fuglestad, O.L., Langfeldt, G., Presthus, A., Skrøvset, S., Stjernstrom, E. and Vedoy, G. (2005), "Successful school leadership: the Norwegian case", in Jacobson, S.L., Day, C. and Leithwood, K. (Eds.), Journal of Educational Administration, The International Successful School Principalship Project Vol. 43 No 6, pp. $584-594$.

Montgomery Van Wart.(2005). Dynamics of Leadership in Public Service. Sage Publications.

Oplatka, I. (2004). The Principalship in Developing Countries: Context, Characteristics and Reality. Comparative Education, 40(3), 427-448.

Ouchi, W.G. (1981) Theory Z: How American Business Can Meet the Japanese Challenge. Reading, MA: Addison-Wesley.

Pascale, R.T. and Athos, A.G. (1981) The Art of Japanese Management: Applications for American Executives. New York: Simon \& Schuster.

Peg Thoms. (2005). Finding the Best and Brightest. A Guide to Recruting, selecting and Retaining Effective Leaders. Praeger. Westport, Connecticut. UK.

Peter Glenn Northhouse. (2009). Introduction to Leadership Concept and Practics. Sage Publications, Inc. Peter Guy North House. (2007). Leadership Theory and Practice ( $4^{\text {th }}$ ed.) Sage Publication.

Peter Guy North House. (2009). Leadership. Theory and Practive. Sage Publication.

Peters, T. and Waterman, R. (1982) In Search of Excellence. New York: Random House.

Peterson, K. D. (2002). The professional development of principals: Innovations and opportunities. Educational Administration Quarterly.38 (2), 213-232. 
Pigford, A.B., \& Tonnson, S. (1993). Women in school leadership. Survival and advancement guidebook. Lancaster, PA: Technomic.

Rakiz, T \& Swason, A (2000). Fundamental Concepts of Educational Leadership: Belmont: Wadsworth Publishing Company.

Ronald E. Riggio Susan E. Murphy, francis J. Pirozzolo (Eds). (2002). Multiple Intelligence and Leadership. Lawrence Erlbaum Associates. NJ. UK.

Shakeshaft, C. (1987). Women in Educational Administration. Newbury Park, CA: Sage.

Southworth, G. (2004). Primary school leadership in context: Leading small, medium and large sized schools. London-New York: Rutledge Falmer.

Stanford, J.H., Oates, B.R. and Flores, D. (1995), "Women's leadership styles: a heuristic analysis", Women in Management Review, Vol. 10 No. 2, pp. 9-16.

Taylor, D.L. and Bogotch, I.E. (1994), "School-level effects of teachers' participation in decision making”, Educational Evaluation and Policy Analysis, Vol. 16, pp. 302-319.

The Arbinger Institute. (2002). Leadership and Self Deception: Getting out of the Box. Berrett - Koehler Publishers.

Thomas J. Sergiovanni. (2001). Leadership: What is in it for schools. Routledge Falmer. London. UK. Tony Bush. (2003). Theories of Educational Leadership and Management (3rd Edition).Sage Publication.

Ulrich, D., Zenger, J. and Smallwood, N. (1999). Results-Based Leadership: How Leaders Build the Business and Improve the Bottom Line. Harvard Business School Press

W. Glenn Rowe. (2007). Cases in Leadership. Sage Publication.

W. Glenn Rowerad Lawra Guerrero. (2010). Cases in Leadership. Sage Publications.

Wagner, C. G. (2001). New direction for leaders: Future scope 2001. Futurist, 35 (6), p. 57.

Waldman, D. A., Ramirez, G. G., House, R. J. \&Puranam. (2001). Does leadership matter? CEO leadership attributes and profitability under conditions of perceived environmental uncertainty. Academy of Management Journal, 44, 134-143.

Waldman, D.A., \& Yammarino, F.J. (1999). CEO charismatic leadership: Levels-of-management and levels-of-analysis effects. Academy of Management Review, 24, 266-285.

Waldman, D.A., Atwater, L.E. \& Antonioni, D. (1998). Has 360-degree feedback gone amok? Academy of Management Executive, 12, 86-94.

Waldman, D.A., Ramirez, G.G., House, R.J. \& Puranam. (2001). Does leadership matter? CEO leadership attributes and profitability under conditions of perceived environmental uncertainty. Academy of Management Journal, 44, 134-143.

Wallace, M. (2002), "Modeling distributed leadership and management effectiveness: Primary school senior management teams in England and Wales", School Effectiveness and School Improvement, Vol. 13 No. 2, pp. 163-186.

Welch, A. (2007). Making Education Policy UK: Oxford University Press. 


\section{Macrothink}

Journal of Public Administration and Governance

ISSN 2161-7104

2012, Vol. 2, No. 1

Wren, J. T. (ed.) (1995). The leader's companion: Insights on leadership through the ages.

New York: Free Press.

Young, M. D. (2002, February). Ensuring the university's capacity to prepare learning-focused leadership.

Report presented at the meeting of the National Commission for the Advancement of Educational Leadership, Racine, WI.

Yulk, G. (2002). Leadership in Organization ( $5^{\text {th }}$ Edition). Upper Saddle River, NJ: Prentice Hall.

Zalenik, A. (1992). Managers and leaders: are they different? Harvard Business Review.

March/April, p 126.

\section{Appendix A:}

\section{Leadership Questionnaire}

\section{Leader Behavior Description Questionnaire (LBDQ)}

Given below is a list of statements that may be used to describe about leadership Behavior of your head. Each statement describes a specific kind of Behavior, but does not ask you to judge whether the Behavior is desirable of undesirable. Read each one carefully, and then using the following scale, decide as actually and accurately as you can the Behavior of your head. Please put a $(\sqrt{ })$ in the appropriate column to the right of each statement.

Letters from $\mathrm{A}-\mathrm{E}$ represent following argument with the statements.

A Always
B Often
C Occasionally
D Seldom
E Never
\begin{tabular}{|l|l|l|l|l|l|l|}
\hline \multicolumn{1}{|c|}{ Code } & Statement about Leadership Behavior & A & B & C & D & E \\
\hline R-O1 & S/he is a good listener. & & & & & \\
\hline R-O2 & S/he handles conflict with a minimum of discomfort. & & & & & \\
\hline R-O3 & S/he is courteous, self-controlled, patient and use discretion in & & & & & \\
\hline R-O4 & S/he is trustworthy and exhibits confidence and trust in others. & & & & & \\
\hline
\end{tabular}




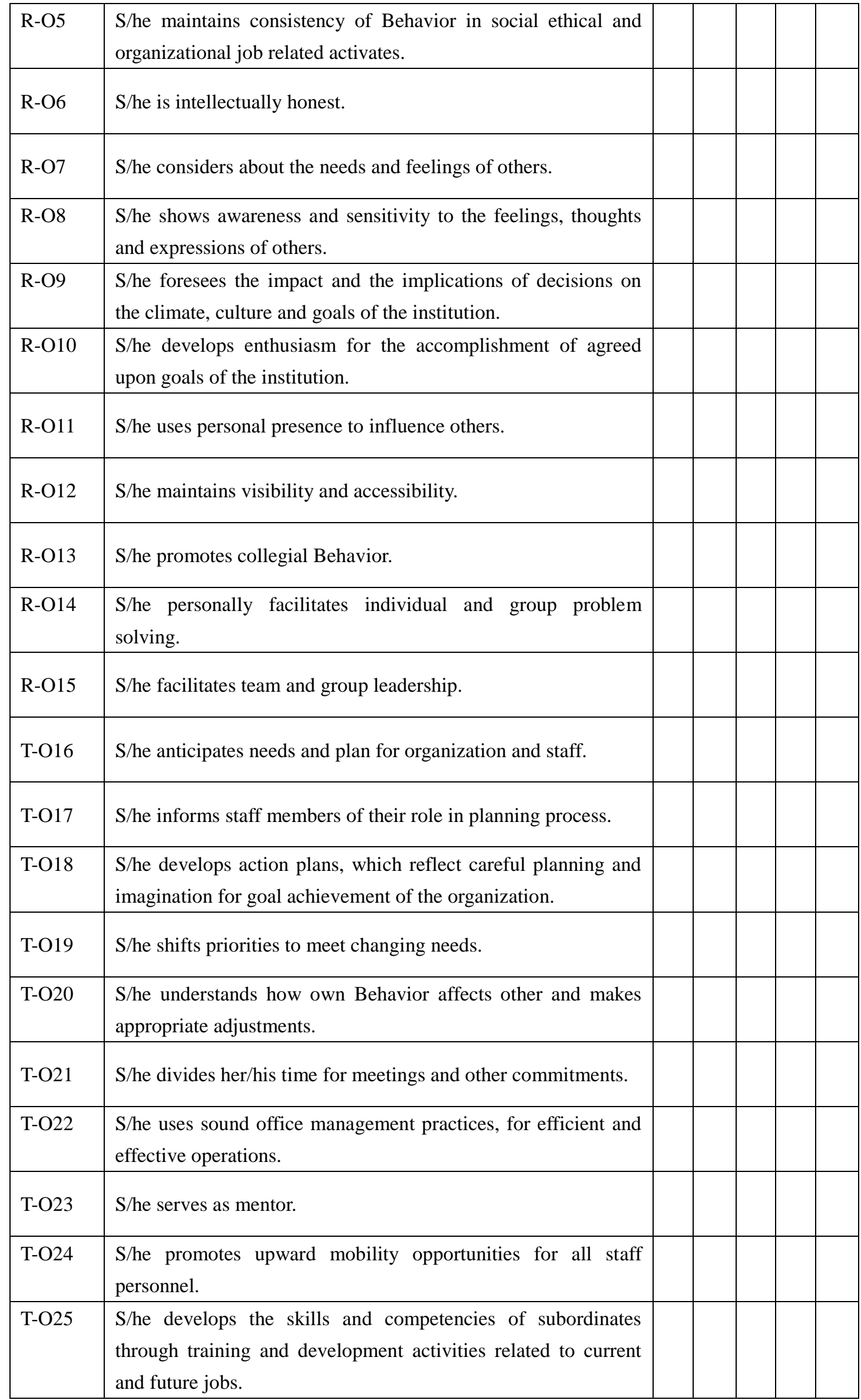




\begin{tabular}{|c|c|}
\hline T-O26 & $\begin{array}{l}\text { S/he utilizes subordinates effectively by allocating } \\
\text { decision-making and other responsibilities to the appropriate } \\
\text { subordinates. }\end{array}$ \\
\hline $\mathrm{T}-\mathrm{O} 27$ & $\begin{array}{l}\text { S/he delegates task within the scope of subordinates' job } \\
\text { description, which maximizes staff's ability and potential. }\end{array}$ \\
\hline $\mathrm{T}-\mathrm{O} 28$ & S/he studies and analyzes program evaluation results. \\
\hline T-O29 & $\begin{array}{l}\text { S/he uses evaluation results to develop a follow-up plan for } \\
\text { institutional improvement. }\end{array}$ \\
\hline T-O30 & $\begin{array}{l}\text { S/he uses different methods and techniques of evaluation to the } \\
\text { current programs/activities for refining and improving them. }\end{array}$ \\
\hline
\end{tabular}




\section{Appendix B:}

\section{Leadership Questionnaire}

\section{Institution Performance Questionnaire (IPQ)}

Given below is a list of statements to diagnose the optimal impact of leadership Behavior of your head on effective performance of institution for achieving the goals of education as laid down in the national documents? Please put a $(\sqrt{ })$ to the appropriate column to the right of each statement.

Letters from A - E represent the following statements.
A Always
B Often
C Occasionally
D Seldom
E Never

\begin{tabular}{|c|c|c|c|c|c|c|}
\hline Sr. No & Statement about Institution Performance & $A$ & $B$ & $C$ & $D$ & $E$ \\
\hline 1 & $\begin{array}{l}\text { S/he develops functional and working atmosphere in the } \\
\text { institutions. }\end{array}$ & & & & & \\
\hline 2 & S/he disposes the institutional tasks swiftly as per rules. & & & & & \\
\hline 3 & $\begin{array}{l}\text { S/he makes the students and staff to enjoy more academic } \\
\text { freedom. }\end{array}$ & & & & & \\
\hline 4 & S/he implements the calendar of activities in true letter and sprite. & & & & & \\
\hline 5 & $\begin{array}{l}\text { S/he utilizes human resources for better institutional efficiency } \\
\text { and performance. }\end{array}$ & & & & & \\
\hline 6 & $\begin{array}{l}\text { S/he directs the staff to be regular and efficient in the discharge of } \\
\text { their duties. }\end{array}$ & & & & & \\
\hline 7 & $\begin{array}{l}\text { S/he believes in consultation, discussion and seeking advice for } \\
\text { the betterment of the institution. }\end{array}$ & & & & & \\
\hline 8 & $\begin{array}{l}\text { S/he shows concern and sensitizes the youth for better output of } \\
\text { the institution. }\end{array}$ & & & & & \\
\hline 9 & $\mathrm{~S} /$ he tries to come up to the aspirations of the community. & & & & & \\
\hline 10 & $\begin{array}{l}\text { S/he develops cohesiveness among the staff for fulfilling the } \\
\text { goals of the institution. }\end{array}$ & & & & & \\
\hline 11 & S/he believes in the academic audit of the staff and performance & & & & & \\
\hline
\end{tabular}




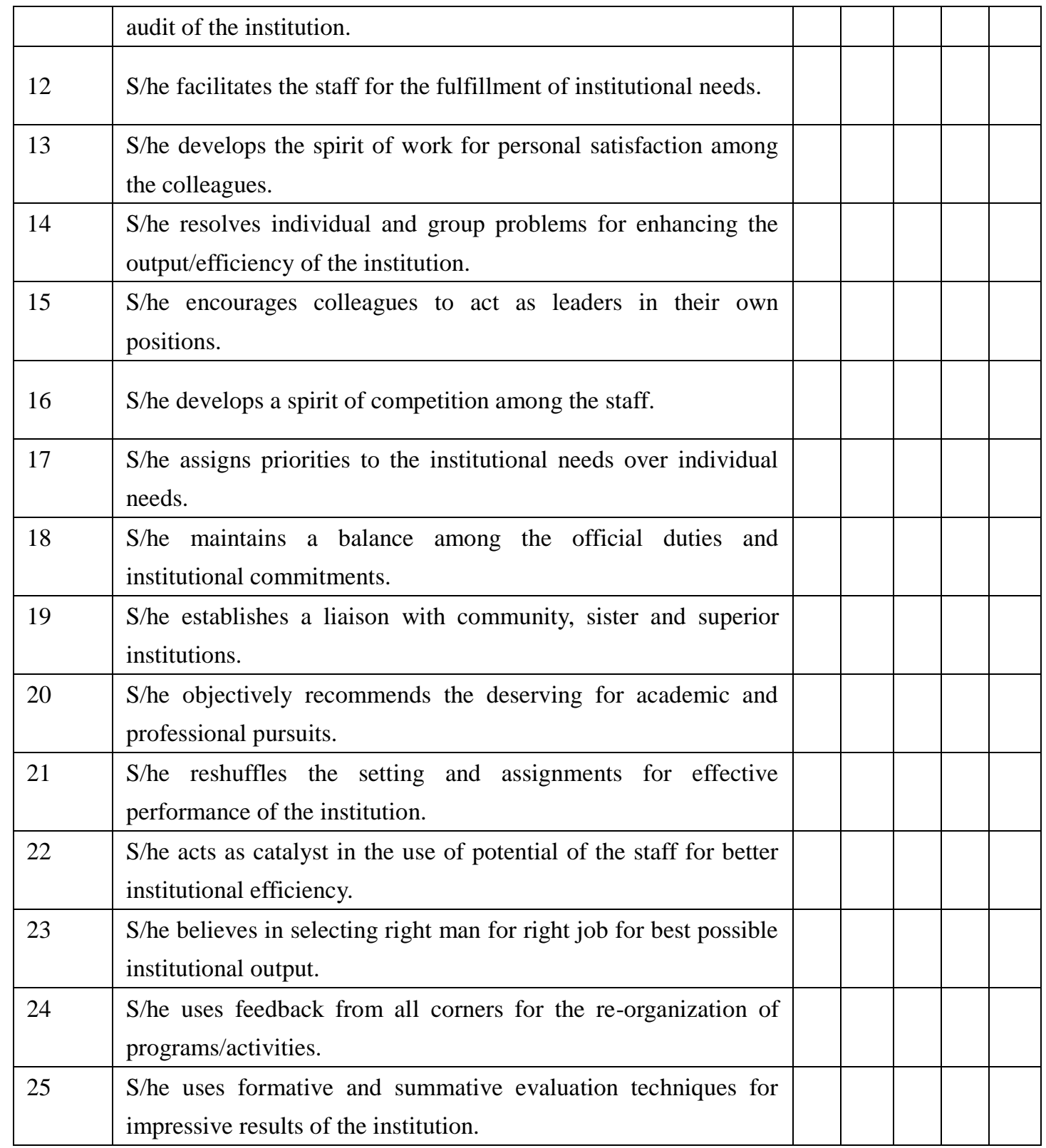


Appendix C:

\section{Leadership Questionnaire}

Leadership Demographics (Attributes + Situational factors) Checklist (LDC)

1. Express Age

Y M

2. Experience as head/Administrative position

D

$\mathrm{Y}$

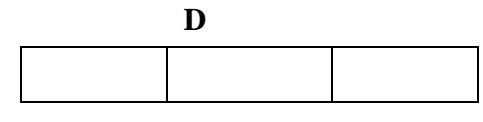

3. Stay in Education Department

Y

M

\begin{tabular}{|l|l|l|}
\hline $\mathrm{M}$ & $\mathrm{D}$ \\
\hline & & \\
\hline
\end{tabular}

4. Length of time spent in Academic pursuit

$\mathrm{Y}$

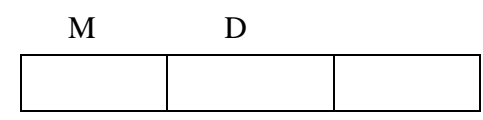

(Norm reference)

16 years=M.A/M.Sc

19 years $=$ M.Phil

23 years $=$ Ph.D

$\mathbf{Y}$

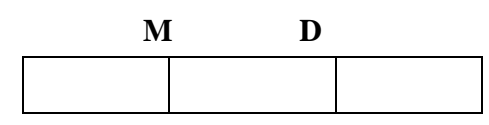

(Norm reference)

02years =.A. (Education)

04years=MA. (EPM) after M.A 
Education/M.Ed.

01year $=$ B.Ed

02years =M.Ed after B.Ed

6. No. of Management courses attended

(Tick one)

\begin{tabular}{|l|l|}
\hline 1 & \\
\hline 2 & \\
\hline 3 & \\
\hline 4 & \\
\hline 5 and above & \\
\hline
\end{tabular}


7. Total staff (Teaching + Non-teaching) Pay scale wise

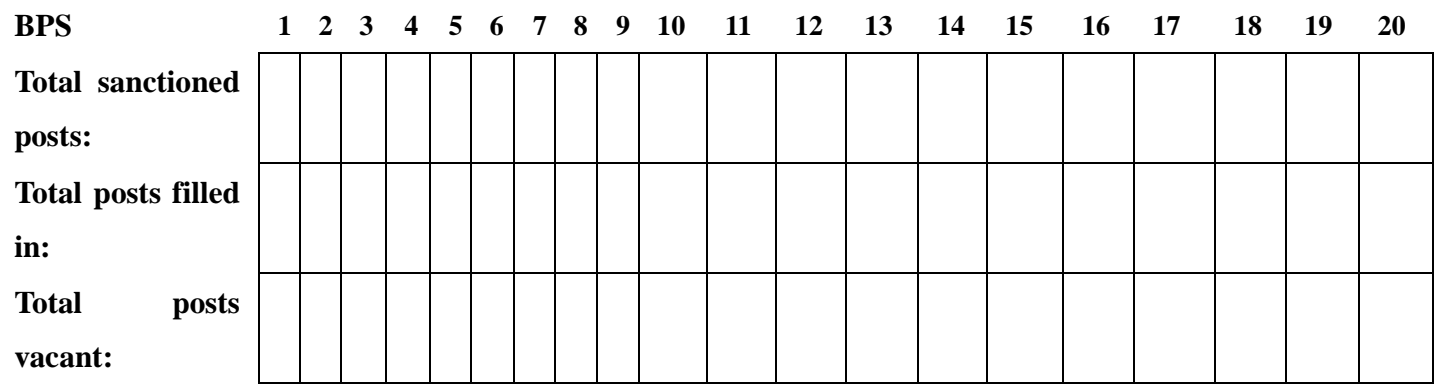

\section{Quantitative Institutional Performance}

8.1 Higher Secondary Level results (if applicable)

\begin{tabular}{|l|l|l|l|l|l|l|}
\hline Year & Appeared & Passed & \%age & I Div. & II Div. & III Div. \\
\hline 2000 & & & & & & \\
\hline 2001 & & & & & & \\
\hline 2002 & & & & & & \\
\hline
\end{tabular}

8.2 Graduate Level results (if applicable)

\begin{tabular}{|l|l|l|l|l|l|l|}
\hline Year & Appeared & Passed & \%age & I Div. & II Div. & III Div. \\
\hline 2000 & & & & & & \\
\hline 2001 & & & & & & \\
\hline 2002 & & & & & & \\
\hline
\end{tabular}

8.3 Professional Degree Level results (if applicable)

B.Ed.

\begin{tabular}{|l|l|l|l|l|l|l|}
\hline Year & Appeared & Passed & \%age & I Div. & II Div. & III Div. \\
\hline 2000 & & & & & & \\
\hline 2001 & & & & & & \\
\hline 2002 & & & & & & \\
\hline
\end{tabular}

8.4 Professional Degree Level results (if applicable)

M.Ed.

\begin{tabular}{|l|l|l|l|l|l|l|}
\hline Year & Appeared & Passed & \%age & I Div. & II Div. & III Div. \\
\hline 2000 & & & & & & \\
\hline
\end{tabular}




\begin{tabular}{|l|l|l|l|l|l|l|}
\hline 2001 & & & & & & \\
\hline 2002 & & & & & & \\
\hline
\end{tabular}

8.5 Institutions under your administrative control. (if applicable) EDO $($ GHSS + GDC + GCE $)$

(Tick one)

\begin{tabular}{|l|l|}
\hline $1-5$ & \\
\hline $6-10$ & \\
\hline $11-15$ & \\
\hline $16-20$ & \\
\hline $21 \&$ above & \\
\hline
\end{tabular}


8.6 Institutions under your administrative control. (if applicable) DEO (GHSS)

(Tick one)

\begin{tabular}{|l|l|}
\hline $1-5$ & \\
\hline $6-10$ & \\
\hline $11-15$ & \\
\hline $16-20$ & \\
\hline $21 \&$ above & \\
\hline
\end{tabular}

8.7 Institutions visited during an academic calendar (if applicable) EDO $($ GHSS + GDC + GCE)

(Tick one)

\begin{tabular}{|l|l|}
\hline $1-5$ & \\
\hline $6-10$ & \\
\hline $11-15$ & \\
\hline $16-20$ & \\
\hline $21 \&$ above & \\
\hline
\end{tabular}

8.8 Institutions visited during one academic calendar (if applicable) DEO (GHSS)

(Tick one)

\begin{tabular}{|l|l|}
\hline $1-5$ & \\
\hline $6-10$ & \\
\hline $11-15$ & \\
\hline $16-20$ & \\
\hline $21 \&$ above & \\
\hline
\end{tabular}

8.9 P.C-I prepared and submitted. (if applicable)

EDO $($ GHSS + GDC +GCE)

\begin{tabular}{|l|l|}
\multicolumn{1}{c|}{ (Tick one) } \\
\hline $1-5$ & \\
\hline $6-10$ & \\
\hline $11-15$ & \\
\hline $16-20$ & \\
\hline $21 \&$ above & \\
\hline
\end{tabular}


8.10 P.C-I prepared and submitted. (if applicable) DEO (GHSS)

(Tick one)

\begin{tabular}{|l|l|}
\hline $1-5$ & \\
\hline $6-10$ & \\
\hline $11-15$ & \\
\hline $16-20$ & \\
\hline $21 \&$ above & \\
\hline
\end{tabular}

